Journal Of Agriculture and Social Research (JASR) Vol. 8, No.1, 2008

\title{
THE EFFECTS OF DIFFERENT GONADOTROPHIN TREATMENTS ON THE EMBRYO GENERATION AND QUALITY OF EMBRYOS IN WEST AFRICAN DWARF GOATS
}

\section{IHEUKWUMERE, F. C.}

\begin{abstract}
The effects of Ovine FSH, Porcine FSH (FSH-P) and HMG treatments on embryo generation and embryo quality were studied in West African dwarf goats The results on the number of corpora lutea (CL) on the ovary was (10.12 \pm 0.06$)$ in FSH-P and (11.35 \pm 1.75$)$ in FSH-O. However, they differed significantly $(P<0.05)$ from $H M G(8.02 \pm 2.15)$ in $C L$ values. The number of embryos recovered in FSH-P (7.25 \pm 0.04$)$ and FSH-O (7.85 \pm 0.06$)$ were similar $(P>0.05)$, but differed significantly $(P<0.05)$ from $H M G(5.15 \pm 0.03)$. The ova/embryo wastage was not significantly different $(P>0.05)$ between $T_{1} F S H-P(14.75 \pm 0.06 \%)$ and $T_{2} F S H-O(13.54 \pm 0.14 \%)$, however, they differed significantly $(P<0.05)$ from $T_{3} H M G(18.24 \pm 0.10 \%)$. Embryo recovery rate of goats treated with $T_{1}$ FSH-P $(85.02 \pm 0.06 \%)$ however, differed significantly $(P<0.05)$ from $T_{3}$ $H M G(68.24 \pm 1.24 \%)$. Goats treated with $T_{2} F S H-O$ recorded higher fertilized embryos of 12.45 \pm 1.65 which differed significantly $(P<0.05)$ from $T_{1} F S H-P(7 .-0 \pm 2.15)$ and $T_{3} H M G(6.16 \pm$ 1.12). The number of non-transferable embryos showed no significant difference $(P>0.05)$ between the treatment groups. The results of this study indicated that FSH-O is the gonadotrophin of choice for goat superovulation.
\end{abstract}

Key Words: Embryo generation, quality, Gonadotrophins, goats.

\section{INTRODUCTION}

The primary goal of superovulation is to obtain consistent high number of viable good quality embryos from each donor (Nowshari et al. 1995; Senthilkumar et al., 1998). Despite research efforts made during the last three decades, marked variability in the yield of transferable embryos is still considered to be the major limiting factor in the success of Multiple Ovulation and Embryo Transfer (MOET) programmes in goats (Senthilkumar et al., 1998). The quality of embryo is influenced by the type and amount of gonadotrophin preparations used (Armstrong, 1993) FSH + LH ratio (Dixon and Hopkins, 1996), status of follicular development at the time of initiation of superovulation treatment (Nowshari et al., 1995) and endocrine status of the animal (Alcivar et al., 1992). The present study was designed to evaluate the influence of Porcine FSH, Ovine FSH and Human Menopausal Gonadotropin (HMG) treatments on the embryo generation and quality of West African dwarf goats.

\section{MATERIALS AND METHODS}

Eighteen (18) healthy, parous, cyclical West African dwarf goats were used for this study. The goats were divided into three treatment groups consisting of six goats in each group identified as $\mathrm{T}_{1}$, $\mathrm{T}_{2}$ and $\mathrm{T}_{3}$. $\mathrm{T}_{1}$ was administered with Porcine FSH - FSH-P; $\mathrm{T}_{2}$ with Ovine FSH, FSH-O and $\mathrm{T}_{3}$ with HMG (Pergonal ${ }^{\circledR}$ ) consisting of FSH + LH in a ratio 1:1 (Dixon and Hopkins, 1996) in a completely randomized design (CRD). $\mathrm{T}_{1}$ group of goats were superovulated using $180 \mathrm{mg}$ NIHFSH-PI (Folltropin-V Vetrapharm Inc. Canada) in 8 divided step-down dose, $\mathrm{T}_{2}$ was administered with 190 mg NIH-FSH-O I (Ovagen, Immuno chemical Products Ltd., Newzeland) in eight divided equal doses and $\mathrm{T}_{3}$ was superovulated using $1000 \mathrm{IU}$ HMG (Pergonal ${ }^{\circledR}$, Ferring Labs, USA) as single dose respectively. The estrous cycle was controlled by using $3 \mathrm{mg}$ norgestomet ear implant for 13 days.

\section{Detection of oestrus}


After implant removal, the goats were watched closely for obvious signs of heat as described by Akusu and Egbunike (1990). As soon as the Does came on heat, they were mated to virile buck. This usually took place early in the morning before mid-day. In order to make sure, mating took place, even at other times, the buck was left with the does throughout the heat period which lasted 2 -4 days.

\section{Recovery and Evaluation of Embryos}

The embryo recovery method used in this trial is laparatomy as described by Senthilkumar et al. (1998), Goel and Agrawal (1998). In this method, embryo collection was carried out under general anaesthesia using chlorpromazine with ovaries oviducts and uterus exposed by a midventral incision. Oviducts were cannulated, via the fimbrae and part or all the reproductive tract was flushed by gently expressing the recovery medium along the uterine horns and the fallopian tube. The parameters for embryo generation evaluated were (1) Number of corpora lutea on the ovary (2) Number of embryos recovered (3) Embryo recovery rate (4) Ova/embryo wastage. Embryo quality was assessed by grading them based on their morphological characteristics. They were assessed as excellent, good, fair and poor based on their morphological status. The morphology of embryos considered are as flows: Identification of uncleaved, degenerated or regular embryos, the stage of development, integrity of the zona pellucida, nature of the cell surrounding the embryo and the colour of the cytoplasm. The embryos were microscopically evaluated at $\mathrm{x} 70$. These were carried out at the Histology Unit of the University of Port-Harcourt Teaching Hospital Port-Harcourt, Nigeria. The excellent and good quality embryos were considered as transferable embryos; while fair and poor quality embryos were considered as non-transferable.

\section{Data analysis}

All the data collected from this study were subjected to analysis of variance, Steel and Torrie (1980). Significant treatment means were separated by Duncan's New Multiple Range Test as described by Obi (1990).

\section{RESULTS AND DISCUSSION}

The results of the different gonadotrophin treatments on embryo generation in West African dwarf goats are shown in Table 1. The number of corpora lutea (CL) on the ovary did not differ significantly $\left(\mathrm{P}>0.05\right.$ ) between goats superovulated with $\mathrm{T}_{1} \mathrm{FSH}-\mathrm{P}$ and $\mathrm{T}_{2} \mathrm{FSH}-\mathrm{O}$, but, they differed significantly $(\mathrm{P}<0.05)$ from $\mathrm{T}_{3}$ HMG. The higher $\mathrm{CL}$ value observed in FSH-O superovulated goats is comparable to the findings of Senthilkumar et al. (1998) in Malabari goats, but higher than CL number reported by Pereira et al. (1998), Goel and Agrawal (1998) respectively in goats. The observed similarity in CL numbers of FSH-P and FSH-O treated goats indicate the efficacy of the two gonadotrophins in enhancing ovarian activity in goats. 
Journal Of Agriculture and Social Research (JASR) Vol. 8, No.1, 2008

Table 1: Effect of different gonadotrophins on embryo generation in West African dwarf goats

\begin{tabular}{llll}
\hline \multirow{2}{*}{ Parameters } & \multicolumn{2}{l}{ Treatment (Gonadotrophins) } & \\
\cline { 2 - 4 } & $\mathbf{T}_{\mathbf{1}}$ & $\mathbf{T}_{\mathbf{2}}$ & $\mathbf{T}_{\mathbf{3}}$ \\
& FSH-P & FSH-O & HMG \\
\hline No. of corpus luteum & $10.12 \pm 0.06^{\mathrm{a}}$ & $11.35 \pm 1.75^{\mathrm{a}}$ & $8.02 \pm 2.115^{\mathrm{b}}$ \\
No of embryos recovered & $7.25 \pm 0.04^{\mathrm{a}}$ & $7.85 \pm 0.06^{\mathrm{a}}$ & $5,15 \pm 0.03^{\mathrm{b}}$ \\
Ova/embryo wastage $(\%)$ & $14.75 \pm 0.06^{\mathrm{b}}$ & $13.54 \pm 0.14^{\mathrm{b}}$ & $18.24 \pm 010^{\mathrm{a}}$ \\
Embryo recovery rate $(\%)$ & $85.02 \pm 0.06^{\mathrm{a}}$ & $88.50 \pm 0.08^{\mathrm{a}}$ & $68.24 \pm 24^{\mathrm{b}}$ \\
\hline
\end{tabular}

a'b: Means within row with different superscripts are significantly different $(\mathrm{P}<0.05)$

\section{Table 2: Effect of different gonadotrophins on the embryo quality of West African dwarf goats.}

\begin{tabular}{|c|c|c|c|}
\hline \multirow[b]{2}{*}{ Parameters } & \multicolumn{3}{|c|}{ Treatment (Gonadotrophins) } \\
\hline & $\begin{array}{l}T_{1} \\
\text { FSH-P }\end{array}$ & $\begin{array}{l}\mathrm{T}_{2} \\
\text { FSH-O }\end{array}$ & $\begin{array}{l}T_{3} \\
\text { HMG }\end{array}$ \\
\hline Fertilized embryos & $7.0+2.15^{b}$ & $12.45+1.65^{\mathrm{a}}$ & $6.1^{6}+1.12^{b}$ \\
\hline Transferable embryos & $4.0 \pm 0.02^{\mathrm{b}}$ & $8.15 \pm 1.01^{\mathrm{a}}$ & $3.25 \pm 0.03^{B}$ \\
\hline (a) Excellent & $3.00 \pm 1.24^{\mathrm{b}}$ & $5.10 \pm 1.35^{\mathrm{a}}$ & $2.65 \pm 0.73^{b}$ \\
\hline (b) Good & $1.00 \pm 0.34^{\mathrm{b}}$ & $3.05 \pm 0.75^{\mathrm{a}}$ & $1.00 \pm 0.31^{\mathrm{b}}$ \\
\hline Non-transferable & $0.75 \pm 0.43^{b}$ & $1.15 \pm 0.41^{\mathrm{a}}$ & $0.30 \pm 0.15^{\mathrm{b}}$ \\
\hline (a) Fair & $0.44 \pm 0.21^{\mathrm{a}}$ & $0.68 \pm 0.24^{\mathrm{a}}$ & $0.18 \pm 0.13$ \\
\hline (b) Poor & $0.31 \pm 0.18^{\mathrm{b}}$ & $0.47 \pm 0.35^{\mathrm{a}}$ & $0.12 \pm 0.16^{\mathrm{c}}$ \\
\hline Unfertilized ova & $0.31 \pm 0.18$ & $1.75 \pm 0.62$ & $0.60 \pm 0.21$ \\
\hline
\end{tabular}

a' b'c: Means within row with different superscripts are significantly different

$(\mathrm{P}<0.05)$

This is in agreement with the reports of Senthilkumar et al. (1998) in Malabari goats.

The number of embryos recovered from FSH-P treated goats and

FSH-O treated goats showed no significant differences $(\mathrm{P}>0.05)$ between the treatment groups. However, they differed significantly $(\mathrm{P}<0.05)$ from HMG treated goats. In this study, the higher number of embryos recovered in FSH-O treated goats was comparably higher than the figures reported by Rathore et al. (1998), Goel and Agrawal (1998) and Iheukwumere (2004) respectively in goats. The goats superovulated with HMG showed low number of embryo recovered compared with the other treatments. The low number of embryos recovered in this group of goats might be due to excessive oestradiol level in the circulation during early luteal phase (Goel and Agrawal, 1998) and for premature release of postaglandin $\mathrm{F}_{2} \alpha$ (Pereira et al., 1998). The similarity between $\mathrm{T}_{1}$ FSH-P and $\mathrm{T}_{2}$ FSH-O in the number of embryos recovered in this study confirms the efficacy of the gonadotrophins in inducing superovulation and enhancing ovarian activity in goats. These results agree with the reports of Senthilkumar et al. (1998) and Iheukwumere (2004) in goats.

The ova/embryo wastage was not significant $(\mathrm{P}>0.05)$ between $\mathrm{T}_{1}$ FSH-P and $\mathrm{T}_{2}$ FSH-O. However they differed significantly $(\mathrm{P}<0.05)$ from $\mathrm{T}_{3} \mathrm{HMG}$ treated goats. Goats treated with $\mathrm{T}_{3}$ HMG showed higher ova/embryo wastage compared with the other treatment groups. The low ova/embryo wastage and similarities observed in goats treated with FSH-P and FSH-O indicate the efficacy of the gonadotrophins in super ovulation of West African dwarf goats. This observation is in agreement with the reports of Herbert et al. (2000) and Lozano et al. (2000) in ewes. 
Embryo recovery rate of goats treated with $\mathrm{T}_{1}$ FSH-P and $\mathrm{T}_{2} \mathrm{FSH}-\mathrm{O}$ showed no significant differences $(\mathrm{P}>0.05)$ between treatment groups, however, they differed significantly $(\mathrm{P}<0.05)$ from $\mathrm{T}_{3}$ HMG in embryo recovery rate. The higher embryo recovery rate observed in goats treated with FSH-O was comparably higher than the $75 \%$ reported by Rathore et al (1998), but, favourably comparable with embryo recovery rate of $85.5 \%$ reported by Pereira et al. (1998) in goats treated with prostaglandin $\mathrm{F}_{2} \alpha$ before flushing.

The results of different gonadotrophins on embryo quality of West African dwarf goats are shown on Table 2. The goats superovulated with $\mathrm{T}_{2}$ FSH-O recorded higher fertilized embryos, which differed significantly $(\mathrm{P}<0.05)$ from $\mathrm{T}_{1}$ FSH-P and $\mathrm{T}_{3} \mathrm{HMG}$. The fertilized embryos did not differ significantly $(\mathrm{P}>0.05)$ between $\mathrm{T}_{1} \mathrm{FSH}-\mathrm{P}$ and $\mathrm{T}_{3} \mathrm{HMG}$. The number of unfertilized ova showed no significant differences $(\mathrm{P}>0.05)$ between the three treatment groups. The low incidence of unfertilized oocytes in the three experimental groups indicates the fertility of the bucks and the effectiveness of the breeding programme practiced in this study. This observation is in agreement with the findings of Senthilkumar et al. (1998) in goats.

It is observed that higher number of ovulations over an extended period of time impedes the fertilization process (Armstrong, 1993). In this study, the number of unfertilized oocytes were numerically higher in FSH-O treatment group. Senthilkumar et al. (1998) reported similar findings in Malabari goats.

Goats superovulated with $\mathrm{T}_{2}$ FSH-O showed higher transferable embryos which differed significantly $(\mathrm{P}<0.05)$ from $\mathrm{T}_{1}$ FSH-P and $\mathrm{T}_{3}$ HMG. However, the excellent quality embryos were significantly higher $(\mathrm{P}<0.05)$ in both the FSH-P and FSH-O treatment groups than in the HMG group. The major factors responsible for the low yield of transferable embryos in HMG group may be due to the presence of prematurely regressing corpus luteum and early onset of oestrus in HMG treated goats (Lauria et al., 1982 and Iheukwumere, 2004). The higher number of transferable embryos in FSH groups might be due to relative increase in progesterone level after oestrus till the day of embryo collection (Britt and Gaska, 1998).

The number of non-transferable embryos showed no significant difference $(\mathrm{P}>0.05)$ between the three treatment groups. However, the higher number of non-transferable embryos in FSH-O group may be due to the yield of proportionally higher number of total embryos than the other two groups. This observation agrees with the reports of Senthilkumar et al. (1998) in goats.

\section{CONCLUSION}

The results of this study suggest that the FSH-O treatment resulted in higher number of total embryos recovered as well as transferable embryos than FSH-P and HMG treatments. Hence, it is recommended that the FSH-O can be used as gonadotrophin of choice for production of more number of transferable quality embryos through superovulation in West African dwarf breed of goats.

\section{REFERENCES}

Akusu, M. O. and Egbunike, G. N., 1990. Effects on oestrus duration of West African dwarf goat. Small Ruminant Research. 3: $413-418$.

Alcivar, A. A., Maurer, R. R. and Andorson, L. L. 1992. Endocrine changes in beef heifers superovulated with follicle stimulating hormone (FSH-P) or human menopausal gonadotrophin. J. Anim. Sci. 70: $274-231$.

Armstrong, D. T. 1993. Recent advances in superovulation of cattle. Theriogenology, 39: $7-24$. 
Britt, J. H. and Gaska, J. 1998. Comparison of two estrous synchronization programme in a large confinement housed dairy herd. Journal of the American Veterinary Medical Assoc. 212 (2): $210-212$.

Dixon, I. E. and Hopkins, G. J. 1996. Superovulation of cattle using porcine pituitary gonadotrophin preparation (Pluset Serono). In: Pluset Scientific Literature Serono Veterinary, Rome, Italy, pp. $22-23$.

Goel, A. K., Agrawal, K. P. 1998. Superovulatory responses and embryos recovery rate in Sirohi goats treated twice with Super-ov, Indian Vet J. 75: 1092 - 1094.

Herbert, U., Okoro, Q. U., Umesiobi, D. O. and Iloeje, M. U. 2000. Effects of the preparations of Clomiphene citrate on the superovulation of West African Dwarf ewes. Proc. $14^{\text {th }}$ Int. Congr. Anim. Reprod., Sweden, 2: 114.

Iheukwumere, F. C., 2004. Embryo collection from West African dwarf goats following treatments for oestrus synchronizing and superovulation. $\mathrm{PhD}$ Thesis, Federal University of Technology, Owerri, Nigeria.

Lauria, A. Olivia, O., Genazzan, A. R., Cremonesi, F., Crotti, S. and Barbett, M., 1982. Improved method to induced ovulation in cattle using human menopausal gonadotrophin (HMG): Theriogenology, 18: $357-364$.

Lozano, J. M., Boland, M. P. and Galloghan, D. 2000. Effect of nutrition on embryo development in ewes. Proc. $14^{\text {th }}$ Int. Congr. Anim. Reprod., Poster $10-23$.

Nowshari, M. A., Beckers, J. F. and Holtz, W. 1995. Superovulation of goats with purified pFSH supplemented with defined amounts of pLH. Theriogenology, 43: $797-802$.

Obi, I. U. 1990. Statistical methods of detecting differences between treatment means. Snaap Press, $2^{\text {nd }}$ ed., Enugu Nigeria, pp. $24-35$.

Pereira, R. J. T. A., Sohnrey, B. and Holtz, W. 1998. Non-surgical embryo collection in goats treated with prostaglandin $\mathrm{F}_{2} \alpha$ and Oxytocin, J. Anim. Sci. 76: $360-363$.

Rathore, J. S., Deen, A., Bishnol, B., Sharma, S. S., Arora, A., Saraswal, P, Chowdhary, F. I. and Gapta, A. K. 1998. Efficiency of different superovulation protocols in Marwani goats. Indian Vet. J. 73: $22-23$.

Senthilkumar, P., Rajasundoram, R. C., Sevaraju, M. and Kathiresan, D. 1998. Effect of inclusion of Norgestomet ear implant in the goat superovulation regimen. Indian Vet. J. 75: 595 597.

Steel, R. G. D. and Torrie, J. H. 1980. Principles and procedures of statistics. A biometric approach, $2^{\text {nd }}$ ed. McGraw-Hill Books, Co. Inc. New York. 